weak tea with light food and half an ounce of brandy every four hours. The pulse was 56 and regular. The face and the conjunctivæ were somewhat jaundiced. There was no hesdache or vomiting. The examination of the chest proved to be negative, except that rhonchus and sibilus were heard at the left base behind. There was some cough with expectoration. The heart's apex beat was situated at the fifth interval, half an inch inside the nipple line. There was no distension of the abdomen and no perceptible enlargement of the liver ; liver dulness appeared to be natural. Stomach resonance was normal. The urine was rather dark, but did not contain bile pigment. The fæces were hard and of a dark colour. At 9.30 P.M. he was given bromidia, dr. $i$, with water to one ounce, to be taken at once as a draught. On the 24 th he had not much sleep. The pulse was 62 . He had some cough. The hiccough had been very severe during the previous night, worse than before; he had, however, taken food well. Dr. Walter R. Jordan of Birmingham kindly saw the patient in consultation with me, and the following medicine was tried: ammoniated tincture of valerian, dr. vi.; bromide of potassium, dr. ii.; chloral hydrate, gr. xc.; with water to six ounces; one ounce to be taken every four hours. On the 25 th he had five hours' sleep, during which time the hiccough stopped, but recommenced on his waking. He had a good breakfast. At 6.30 P M. I was sent for because the patient was "not himself," delirious and drowsy, these symptoms apparently coming on suddenly after a copions motion at midday. The patient was now very drowsy and talking nonsense; his face was flushed; he could, however, be roused, and then complained of severe girdle pain at the epigastric level. The pulse was steady, the tension being low. The hiccough was severe. He also complained of a tingling sensation over the chest and arms. The medicine was ordered to be stopped and hot coffee to be given. At 10 P.M. he was much less drowsy. The skin was bot, the temperature being normal. The epigastric pain had gone On the 26th, about midnight, he tried to get out of bed. Another dose of bromide and chloral was given, although contrary to orders. He slept for six hours without hiccough. In the morning the patient seemed to be much better. The polse was steady and the bowels were opened. He had a good breakfast. Hiccongh was still frequent. The following was prescribed : chloral hydrate, gr. $x$, , bromide of potassinm, $g r_{\text {. }} X \nabla$. , and water to one ounce, to be taken at 3 P.M. At 9.30 P.M., after the dranght, be slept for five hours. He took food well, but the congh was troublesome. The pulse was good. The urine was of sp. gr. 1015 and contained no albumen. On the 27 th he had a fair night. For the first time since the onset of the illness, eleven days previously, he was free from hiccough whilst awake. The pulse was rather weak, but regular and not hurried. He woke up suddenly in the night, startled, and coughed much for a short time. Brandy was increased to one ounce every four hours. Expectorant medicine was administered. At 9.30 P. M. the hiccough had returned, being frequent but not very severe; otherwise the patient's condition was satisfactory, though he felt weak. The pulse was stronger. The dranght as given on March $26 \mathrm{th}$ was repeated. On the 28th the patient took the dranght at midnight and slept well. His condition was quite satisfactory. There was no hiccough, but the voice was husky. The pulse was good. At 9.30 P.M. he had been without hiccough all day. The voice was still husky and the throat sore. There was some pracordial pain during the evening, with throbbing of the heart. The pulse-rate was 52. Examination of the fauces gave a negative result. On the 29 th he had had a good night's rest without the draught. There was no hiccough for twenty-four hours. He felt very weak, but the pulse was good. On his eyes being examined the fundi were found to be normal, as were also the optic discs, but there was abnormal refraction (both eyes $-6 \mathrm{D})$. On the $30 \mathrm{th}$ there was no hiccough. The parient was convaleacent and was allowed to get up for half an hour. On the 31 st his condition vas satisfactory, though be felt very much shaken. He was dressed and came downctairs. The voice was only slightly husky.

Remarks - In this case the bistory of previous attacks of hiccongh and aiso of the "fainting" attacks, which appear to bave been of an epileptiform character, is interesting. In the absence of any obvious cause-e.g., uræmia, new growth, \&c.--one may look upon the attack as a form of epileptic "nerve storm," though, of course, it is possible that there had been some local pathological condition. The pulse, even at the hejght of the attack, was never more than 64 per minute and asually not ovar 56 . The best sign all through the attack was that the patient tock his food well. The severity of the hiccough may be understood by stating that frequently the spasms so shook the body that the bed, a heary one, shook also. No other muscle besides the diaphragm was implicated. The urgent symptoms on the night of March 21st, which made his relatives think that he was dying, were not so very alarming as far as I can make out. Some collection of mucus probably caused the noisy breathing, which seems to have awakened the patient himself, for he woke ap suddenly and asked what was the matter. The bad symptoms on March 25th may, I think, be put down to the doses of chloral that he had taken. There is no family history of paroxysmal neuroses. Leeds-road, Rawdon.

\section{THE TREATMENT OF FRACTURES.}

\section{Bx D. M. BEDDOE, F.R.C.S. ENG.}

THe recent developments in the knowledge of wound infection, and the resulting increase in the means of preventing such, have led medical men to actively interfere for the relief of patients in regions where, without that means, they dare not trespass. In treating any affection the surgeon, now confident in his aseptic precautions, instead of doubtfully asking himself whether he dare make an incision or not, inquires rather what benefit to his patient will accrue therefrom. This being so, it is curious that, with the exception of one or two isolated cases, attempts have not been made to deal more actively with fractared bones than by placing them in splints. Perchance this is due to a want of knowledge of the after-history of persons who bave sustained an injury of this kind. Not long ago, in order to satisfy my mind upon the efficacy of the usual splint treatment of fractures, I made an inquiry inco the subsequent history of a number of persons who had sustained such an injury, taking up for this purpose two particular lesions of the lower extremity-viz., simple fracture of the shaft of the femur and Pott's fracture; and I fear that the results will show that we are no whit better off now than when John Bell said many years ago "that an effectual method of securing oblique fractures in the bones of the extremities, and especially of the thigh bone, is perhaps one of the greatest desiderata of modern surgery, and frequent lameness shows that we are still deficient in this branch of practice." In this investigation I have confined myself almost exclusively to those fractures occurring in working men between the ages of thirty and sixty, as it is for them more particularly that the possession of a firm, stable limb is of such vital importance, and I wish it to be distinctly uxderstood that no selection was employed in their collection. The various details concerning these cases, together with the ascertained results, are given in the annexed tables.

Thus, as regards the 16 cases of fractured femur, the following lamentable results occur: 3 are unable to follow any occupation; 1 is able to do bat a few light odd jobs; 4 cannot work nearly as well as before, and their wage-earning power has much decreased; 1 can do fairly hesvy work, but is unable to climb ladders when carrying weights owing to a stiff knee (he could not do any work for six months); 1 is able to do fairly heavy work, but is out of employment because he could not do any work for seven months ; 4 only can do their work as well as before, and of these one was unable to work for five months and another for three. Of the Pott's fractures, 3 have been able to do but very little work since; 5 are able to do their work only at the cost of some pain and considerable incon. venience (ore of these was five months before he could do any work at all); 1 cannot walk any distance on account of the pain in his ankle and subastragaloid joints ; the remaining 4 are able to do their work satisfactorily, but occasionally suffer from pain in the ankle. When one sees results such as these following treatment, where for broken thigh the patients remained in hospital in no case for less than six weeks, and undex all the advantages that skill and appliances can give, it is surely suggestive that there is something radically wrong in our methods of procedure, and a consideration of the conditions of a recent fracture, and the agencies to be overcome in its proper treatment support this contention; thas, in the case of a 
TABLm I.-Pott's Fractures.

\begin{tabular}{|c|c|c|c|c|c|c|}
\hline No. & Occupation. & $\dot{\Phi}_{\infty}^{\infty}$ & $\begin{array}{l}\text { Date of } \\
\text { fracture. }\end{array}$ & $\begin{array}{l}\text { Time in } \\
\text { hospital. }\end{array}$ & Present condition. & Condition as regards work. \\
\hline 1 & Carman & 30 & 1893 & 14 days & Depression at seat of fracture. & Ankle was very weak for some time; still has \\
\hline 2 & Labourer & 32 & 1893 & 14 days & $\begin{array}{l}\text { Distinct depression } 1 \text { in. above external } \\
\text { malleolus, the displacement of frag- } \\
\text { ments not having becn reduced. }\end{array}$ & $\begin{array}{l}\text { Has continual pain in ankle and subastragaloid } \\
\text { joints; impossible to do anything but the } \\
\text { lightest work, and that with considerable pain. }\end{array}$ \\
\hline 3 & $\begin{array}{l}\text { Bricklayer's } \\
\text { labourer }\end{array}$ & 49 & 1893 & A few days & $\begin{array}{l}\text { Slight depression at seat of fracture; some } \\
\text { eversion still. }\end{array}$ & $\begin{array}{l}\text { Quite unable to do any work for five months; } \\
\text { has been able to do but very little since from } \\
\text { pain in ankle and subastragaloid joints. }\end{array}$ \\
\hline 4 & Accountant & 58 & 1893 & 6 days & Depression at seat of fracture. & $\begin{array}{l}\text { Unable to walk any distance from pain in ankle } \\
\text { and subastragaloid joints. }\end{array}$ \\
\hline 5 & Stickmaker & 64 & 1893 & 14 days & $\begin{array}{l}\text { No displacement, but a little thickening } \\
\text { of bone at seat of fracture. }\end{array}$ & Has pain on standing for some time. \\
\hline 6 & Labourer & 53 & 1891 & A month & $\begin{array}{c}\text { Movement at ankle-joint somewhat } \\
\text { limited. }\end{array}$ & $\begin{array}{l}\text { Returned to work in two months; has suffered } \\
\text { much pain at intervals; ankle still feels very } \\
\text { weak. }\end{array}$ \\
\hline 7 & $\begin{array}{l}\text { Leather- } \\
\text { dresser }\end{array}$ & 27 & 1891 & 3 days & Slight depression at seat of fracture. & $\begin{array}{l}\text { Patient does his work, but suffers great incon- } \\
\text { venience when standing on it for long. }\end{array}$ \\
\hline 8 & $\begin{array}{l}\text { Dock } \\
\text { labourer }\end{array}$ & 35 & 1893 & A few days & No displacement. & Pain on change of weather only. \\
\hline 9 & Labourer & 31 & 1891 & Two days & 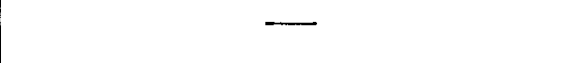 & $\begin{array}{l}\text { Can work as well as ever; very occasional pain } \\
\text { only. }\end{array}$ \\
\hline 10 & $\begin{array}{l}\text { Waterside } \\
\text { labourer }\end{array}$ & 32 & 1892 & Five days & Slight displacement; no deformity. & $\begin{array}{l}\text { Has not been able to do much work since on } \\
\text { account of pain in ankle. }\end{array}$ \\
\hline 11 & Constable & 29 & 1893 & A few days & 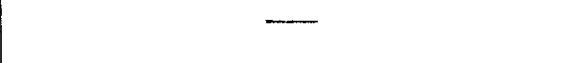 & $\begin{array}{l}\text { Can do his work all right; has occasional pain } \\
\text { only. }\end{array}$ \\
\hline 12 & Porter & 38 & March, 1894 & Seven days & A slight rim at seat of fracture. & $\begin{array}{l}\text { Has a good deal of pain in his foot occasionally, } \\
\text { and is able to follow his employment, but with } \\
\text { some discomfort. }\end{array}$ \\
\hline 13 & Engine man & 48 & Feb., 1894 & A few days & No displacement. & $\begin{array}{l}\text { Can now work as well as before, but he had a } \\
\text { good deal of pain for some months after the } \\
\text { accident. }\end{array}$ \\
\hline
\end{tabular}

TABLE II.-Fractured Shaft of the Femur.

\begin{tabular}{|c|c|c|c|c|c|c|c|c|}
\hline No. & Occupation. & $\underset{80}{*}$ & $\begin{array}{l}\text { Date of } \\
\text { Eracture. }\end{array}$ & Seat of fracture. & $\begin{array}{l}\text { Time in } \\
\text { hospital. }\end{array}$ & $\begin{array}{l}\text { Condition } \\
\text { on } \\
\text { discharge. }\end{array}$ & Present condition. & Capacity for work. \\
\hline 1 & Labourer & 50 & June, 1892 & $\begin{array}{l}\text { Junction of middle } \\
\text { and lower thirds }\end{array}$ & Six weeks & $\begin{array}{l}\text { Satisfactory } \\
\frac{1}{2} \text { in. short }\end{array}$ & $\begin{array}{l}\text { Pain and weakness at } \\
\text { seat of fracture; } \\
\text { pain and stiffness in } \\
\text { knee; no obvious } \\
\text { deformity. }\end{array}$ & $\begin{array}{l}\text { Is unable to follow his regular } \\
\text { employment; can do odd } \\
\text { jobs- only; earns but very } \\
\text { little. }\end{array}$ \\
\hline 2 & Carman & 36 & June, 1890 & Middle third & Eleven weeks & $\begin{array}{l}\text { Apparently } \\
\text { satisfactory }\end{array}$ & $\begin{array}{l}\text { Lame; pain in knee } \\
\text { and hip; knee swells } \\
\text { after walking; bow- } \\
\text { ing of femur. }\end{array}$ & $\begin{array}{l}\text { Cannot work nearly so well as } \\
\text { before accident; was nine } \\
\text { months before he could do } \\
\text { any work at all. }\end{array}$ \\
\hline 3 & Boot welter & 43 & 1392 & $\begin{array}{l}\text { Middle and upper } \\
\text { thirds }\end{array}$ & Seven weeks & $\begin{array}{l}\text { Apparently } \\
\text { satisfactory }\end{array}$ & Lame; pain in thigh. & $\begin{array}{l}\text { Cannot do his work so well; } \\
\text { was eighteen months before } \\
\text { he could work, and then } \\
\text { could not stand for any } \\
\text { length of time. }\end{array}$ \\
\hline 4 & Labourer & 58 & 1890 & $\begin{array}{c}\text { Fracture in two } \\
\text { places }\end{array}$ & Four months & 2 in. short & $\begin{array}{l}\text { Pain and weakness in } \\
\text { limb at seat of frac- } \\
\text { ture and in knee- }\end{array}$ & Has done no work since. \\
\hline 5 & $\begin{array}{l}\text { Riverside } \\
\text { labourer }\end{array}$ & 40 & 1893 & $\begin{array}{l}\text { Upper and middle } \\
\text { thirds }\end{array}$ & Six weeks & $\frac{7}{8} \mathrm{in}$. short & $\begin{array}{l}\text { joint. } \\
\text { Lame; occasional pain } \\
\text { in thigh. }\end{array}$ & $\begin{array}{l}\text { Is not able to work nearly as } \\
\text { well as before; his wage- } \\
\text { earning power has much } \\
\text { diminished; was six months }\end{array}$ \\
\hline 6 & $\begin{array}{l}\text { Fitter's } \\
\text { labourer }\end{array}$ & 55 & 1893 & Upper third & Seven weeks & $\begin{array}{l}\text { Some little } \\
\text { deformity }\end{array}$ & $\begin{array}{l}\text { Lame; pain and inse- } \\
\text { curity in limb; limb } \\
\text { occasionally help- } \\
\text { less, bowing out- }\end{array}$ & $\begin{array}{l}\text { Is not able to work neariy as } \\
\text { well as before; was four } \\
\text { months before he did any- } \\
\text { thing. }\end{array}$ \\
\hline 7 & Blacksmith & 40 & 1894 & Above centre & Nine weeks & - & $\begin{array}{l}2 \frac{1}{2} \text { in. short; increas- } \\
\text { ing pain in knee } \\
\text { and hip; can only }\end{array}$ & $\begin{array}{l}\text { Unable to follow any employ- } \\
\text { ment. }\end{array}$ \\
\hline 8 & Porter & 38 & 1890 & Upper third & - & - & 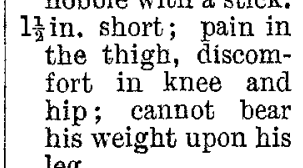 & $\begin{array}{l}\text { Unable to follow any occupa- } \\
\text { tion. }\end{array}$ \\
\hline 9 & $\begin{array}{l}\text { Fngine } \\
\text { druer }\end{array}$ & $5 \hat{8}$ & 1893 & Lower third & Six weeks & $\begin{array}{l}\text { Iin. short ; } \\
\text { adhesion in } \\
\text { knee broken } \\
\text { doxw in } \\
\text { three }\end{array}$ & $\begin{array}{l}\text { No deformity ; slight } \\
\text { pain in ankle on ex- } \\
\text { ertion; foot rotated } \\
\text { inwards slightly. }\end{array}$ & $\begin{array}{l}\text { Can perform heary work, but } \\
\text { is out of employment con- } \\
\text { sequent upon his being } \\
\text { incapacitated for seven } \\
\text { months. }\end{array}$ \\
\hline 10 & Labourer & 32 & 1892 & Lower third & Six weeks & $\frac{x}{2}$ in. short & No pain; not lame; & Can work well. \\
\hline 11 & Carman & 39 & 1892 & Middle and upper & Seven weeks & 1 in. short & $\begin{array}{l}\text { foot turns out a little. } \\
\text { No pain; limps a little. }\end{array}$ & - \\
\hline 12 & Dmyman & 47 & 1890 & $\begin{array}{l}\text { Lower and midalle } \\
\text { thirds }\end{array}$ & Eight weeks & $1 \frac{1}{2}$ in. short & $\begin{array}{l}\text { Good firm limb, but } \\
\text { cannot flex linee to } \\
\text { full extent. }\end{array}$ & $\begin{array}{l}\text { Can work satisfactorily, but } \\
\text { cannot carry weight uphill; } \\
\text { could not work for six }\end{array}$ \\
\hline 13 & Carman & 37 & 1889 & Lower and miclde & Six weeks & ${ }_{2}^{\mathrm{Y}}$ in, short & No lameness and no & Can do his work as well as \\
\hline 14 & Labourer & 29 & 1891 & Middle third & Six weeks & $\frac{2}{2}$ int. short & No lameness and no & Can work well, but could not \\
\hline 15 & Watchman & 42 & 1890 & Middle third & Seven weoks & - & $\begin{array}{l}\text { No lameness, no de- } \\
\text { formity, and no }\end{array}$ & $\begin{array}{l}\text { Can work well, but was unable } \\
\text { to for three nionths. }\end{array}$ \\
\hline 16 & Drayman & 49 & 1893 & $\begin{array}{l}\text { Upper and midile } \\
\text { thirds }\end{array}$ & Nine weeks & in. short & $\begin{array}{l}\text { No lameness, no de- } \\
\text { formity, and no } \\
\text { pain. }\end{array}$ & Can work as well as before. \\
\hline
\end{tabular}


secent fracture of the femur, which in an adult is almost invariably oblique, ${ }^{1}$ we may take it that there is almost al ways some operlapping of the bones, and from the great eversion of the foot, which is almost always constant, there must also be some rotation of the fragments. To take this overlapping first. It is generally said that the cause of this position of the fragments is due, with the exception, perhaps, of the fracturing forcs, to active muscular contraction; but this overlapping is present, and often almost as difficult to reduce when the muscles are fally relaxed under the influence of an anæsthetic as withont, and it seems reasonable to suppose, as Mr. Arbathnot Lane contends, ${ }^{2}$ that the shortening from a broken bane is due to the blood extravasation and effasion into and beneath the soft tissues around the fracture, which bulging out the skin and tissues causes the limb to undergo in proportion a compensatory shortening and resists reduction. of the truth of this observation I am perfectly satisfied, for I have seen several cases where this difficulty of reduction could be explained in no other way. To give an example. Not long since I saw two cases of compound fracture of the leg, in one of which there was a large ragged wound through which the effased blood found a ready exit; whilst in the other there was a much smaller hole partly blocked by the fragment. The former was easily reduced, but the latter, even under an anæsthetic, tazed the full powers of the surgeon to satisfactorily reduce it, although the tendo Achillis had also been divided. I have observed also from records of cases that the amount of shortening is often proportionate to the amount of effusion. It is clear, therefore, that to put up an overlapping fracture in an unyielding envelope such as plaster-of-Paris, as is so often done, simply rebains the fragments in their abnormal relation, in which andesirable position they become permanently fixed. As regards this, the method of continuous extension is infinitely preferable; but even here it seems, to judge by the invariable shortening, that the bones unite sufficiently firmly to prevent full apposition before the counteracting effusion has ceased to act. As Hamilton ${ }^{3}$ says: "When the ends have once become completely displaced no means have yet been devised by which an overlapping and consequent shortening of the bone can generally be prevented." Of fifty cases of fractured femur Mr. Holthouse ${ }^{4}$ found that 90 per cent. had shortening varying from $\frac{1}{2}$ in. to $3 \frac{1}{3}$ in. The application of the various means of extension also is not without grave inconvenienceschafing of the skin, blisters, intractable ulcers, and stiff joints often resulting. As Velpeau says, most of these contrivances fail to obviate the shortening, and produce eschars, ankylosis, or troublesome arrests of the circulation.

With reference to the second displacement-namely, that of rotation - it is curious what little attention has been paid to it. It seems sufficient to the minds of most surgeons to correct the extreme eversion only without any definite rule for its more accurate position. For instance, if the fractured femur be treated by means of a long liston or Desault, the foot is at a right angle to the bed, whereas in a Hodgen the foot may lie in any position from a right angle to as much, perhaps, as $65^{\circ}$. Now, as has been pointed out by Mr. Arbuthnot Lane, ${ }^{5}$ the lower extremity in a position of rest has the foot at an angle of about $45^{\circ}$, the limb rotating outwards from the hipjoint; it is clear, therefore, that if the foot be at a right angle the ends of the fragments do not correspond, but the lower one is twisted inwards to the upper, whilst if the foot be rotated out to an extent exceeding about $45^{\circ}$ there is a twist outwards of the lower fragment. I have seen instances of these conditions both in living subjects and in nuseum specimens of old fractures. Concerning the importance to be attached to a certain amount of overlapping and rotation it may be argued by some that so long as the bones are firmly united a slight amount of shortening is a matter of no moment. Thus Erichsen states " that a slight diminution in the length of a limb is of no consequence, the pelvis remedying this" ; and Hamilton ${ }^{6}$ says "that in shortening over two ifths of an inch either they limp, or they have lifted the beel of the shoe, or, in short, the limping is only concealed by a lateral deviation of the spine." What effect in the long run this deviation has one does not exactly know ; but I have met with sereral instances where the patients have complained of pain and weariness in the back after doing work, which they

Hamilton : Treatise on Fractures and Dislocations, p. 458. Brit. Med. Jour., April, 1895. Fracture, p. 468.

4 Holmes's System of Surgery, second edition, rol it. p. 866

Brit. Hed. Jour., Nov. 11th, 1893 . Fallacy of Vertical Footpiece.
6 Treatise on Fracture, seventh American edition, p. 461 . say they did not experience previously to the occurrence of the fracture. This is suggestive that this compensation on the part of the spine is not altogether to the advantage of the patient. In overlapping of three-fourths of an inch and over, lameness and deformity generally occur, both in some cases being extreme. Out of the sixteen cases nine are lame, eight markedly so.

The evils resulting from the union of fragments rotated upon one another may be less evident at first sight than the lameness resulting from the overlapping, but are on that account none the less real. In this occurrence the dependent joints, which require for the perfect freedom of their action a perfect continuity of the shaft of the bone, suffer undue stress in endeavouring to accommodate themselves to the altered conditions. As Erichsen says: "The rotation outwards of the lower fragment seriously cripples the patient, as the movements of the knee and ankle are rendered almost useless in walking." This undue stress is manifested in two ways : (1) pain and weakness, or limitation of movement in the joint; and (2) organic alterations in the joint or joints. Out of the sixteen cases of fractured femur seven complain of pain in the joints, chiefly that of the knee, but occasionally in the hip and ankle also ; and out of the thirteen cases of Pott's fracture four complain of pain in the subastragaloid joint, and seven in the ankle on exertion. Respecting the organic changes in joints, one is unable to draw any deductions from the above cases on account of their not extending back more than five years, whereas for their full development so as to be manifest externally they would probably require a longer time. I have, however, seen in workhouse patients some good examples of organic change in joints resulting from old fractures of the femur, and these alterations seem to be of the natare of the traumatic arthritis described by $\mathrm{Mr}$. Arbuthnot Lane. ${ }^{7}$ After the lapse of time the lipping of the articular margins and the concurrent changes in the joint itself seriously impede the patient in the performance of his work. An examination of the museum specimens of old fractured femora will often show such a condition of traumatic arthritis.

From a consideration of the above facts it is clear that the object we should strive for in the treatment of fractures is to replace and fix the bone in its original position, and it is also plain that the conditions are such as cannot be entirely remedied by means of splints. To go on treating fractures by such means in the face of results such as the above, where in so many cases the result to the patient is so disastrous, could only be justified if there were absolutely no other means of treatment at our disposal ; but fortunately there is one method which offers a prospect of perfect cure, and that is to cat down upon the seat of fracture and unite the fragments by screw or wire in the exact relation that they occupied previously. The only possible objection to this will be raised by those who are doubtfal of the success of their aseptic precautions. They will probably ask, What if supparation occurs? Yet nevertheless they open the abdominal cavity to remove ovaries and tumours which do not threaten the life of the individual, and they open knee-joints to remove loose bodies which are a source perhaps of disconfort only. Would not suppuration be as disastrous there? That line of argument is surely a wrong one to advance; the only way to deoide the question should be upon grounds such as these: (1) are the present results satisfactory? and, if not, (2) does operation offer a better prospect of fixing the fractured bone in its original position? To the former question there can surely be no other answer after considering the above statistics than that the results are most deplorable, and with reference to the latter I have no hesitation in saying from the cases $I$ have seen done thas that for replacing and fixing the bones in their proper relation, this method is infinitely superior to any means I know.

Guy's Hospital.

The LaATCET, Jan. 30th, 1892.

\section{Nationat Soctety For Eirployment of} EPILEPTIOs - The first annual meeting of governors was held at 12, Buckingham-street. W.C., on Monday, May 27th, the chair being taken by Mr. E. Montefiore Micholls. In a most encouraging report presented by the honorary medical staff it is stated that the experience of the first half-year from the opening of the colony bas been a pleasant surprise even to those who were most sanguine as to the ultimate success of an epileptic colony. 